\title{
Kinerja Keuangan Perbankan Syariah di Indonesia dan Kontribusinya bagi Pembangunan Nasional
}

\author{
Oleh: Yuli Andriansyah ${ }^{1}$
}

\begin{abstract}
This article is aimed to oversee the development of Islamic banking in Indonesia mainly on its financial performance. The financial performance of the Islamic banking is observed in accordance to its blue print in order to evaluate its development and contribution to country development as part its main mission. To some extent, emperical findings suggest that the banking has so far shown its relatively high percieved performance in its financial duty mainly in contributing to financial intermediacies function of banking and to small and medium enterprises development in Indonesia. Nevertheles, some notes should be adressed to banking preference in supporting economic activities of people majority, such as in agriculture and other primary sectors and in implementing its profit and sharing principles in its activities.
\end{abstract}

Kata kunci: perbankan syariah, kinerja keuangan, pembangunan nasional

\section{Pendahuluan}

Pengembangan sebuah sistem perbankan berbasis Islam secara politis di Indonesia akhirnya diakui sebagai bagian dari upaya tujuan pembangunan nasional yaitu untuk mencapai terciptanya masyarakat adil dan makmur berdasarkan demokrasi ekonomi. ${ }^{2} \mathrm{Hal}$ ini antara ditandai dengan peran aktif pemerintah dalam mengembangkan industri perbankan syariah yang diharapkan akan mampu menjadi langkah awal bagi pengembangan sistem ekonomi yang berlandaskan pada nilai keadilan, kebersamaan, pemerataan, dan kemanfaatan

1 Alumni Program Studi Ilmu Ekonomi Pembangunan, Fakultas Ekonomi, Universitas Islam Indonesia. Saat ini bekerja pada Divisi Hubungan Masyarakat, Direktorat Sumber Daya Manusia, Universitas Islam Indonesia. Alamat email: yuliandriansyah@staff.uii.ac.id.

2 Abdul Ghofur Anshori (2009), Perbankan Syariah di Indonesia (Yogyakarta: Gadjah Mada University Press), hal. 7. 
yang sesuai dengan prinsip syariah. Peran aktif ini diturunkan tidak saja dalam level kebijakan perundangan, tetapi juga masuk dalam ranah praktis.

Lahirnya Undang-Undang Nomor 21 Tahun 2008 tentang Perbankan Syariah merupakan bukti pengakuan pemerintah bahwa pengaturan mengenai perbankan syariah yang selama ini ada belum secara spesifik, sehingga perlu dirumuskan perundangan perbankan syariah secara khusus. Sejumlah perundangan memang telah disusun sebelumnya, yaitu Undang-Undang Nomor 7 Tahun 1992 tentang Perbankan sebagaimana telah diubah dengan Undang-Undang Nomor 10 Tahun 1998. Undang-Undang Nomor 7 Tahun 1992 merupakan landasan bagi operasionalisasi perbankan syariah yang saat itu dianggap sebagai bank dengan sistem bagi hasil (profit and loss sharing) dan belum secara spesifik sebagai perbankan dengan nilai-nilai syariah sebagai basis operasionalnya.

Peraturan Pemerintah Nomor 72 Tahun 1992 tentang Perbankan, yang di dalamnya diatur bank berdasarkan prinsip bagi hasil, kemudian mempertegas bagaimana bank bagi hasil ini bekerja dalam perekonomian nasional. Sebagaimana disebutkan di dalamnya, yang dimaksud Bank Bagi Hasil adalah Bank Umum atau Bank Perkreditan Rakyat yang melakukan kegiatan semata-mata berdasarkan prinsip bagi hasil. ${ }^{3}$ Undang-Undang Nomor 10 Tahun 1998 yang lahir kemudian merubahan peraturan perubahan atas Peraturan Pemerintah Nomor 72 Tahun 1992 tentang Perbankan semakin memperkuat kehadiran perbankan syariah di Indonesia. Eksistensi perbankan syariah diakui secara eksplisit melalui Pasal 1 ayat (3) yang menyatakan bahwa bank berdasarkan usahanya dibedakan menjadi bank konvensional dan bank berdasarkan Prinsip Syariah, yang meliputi Bank Umum dan Bank Perkreditan Rakyat. ${ }^{4}$

Seiring dengan makin tingginya kebutuhan akan lembaga keuangan berbasis syariah, maka Undang-Undang Nomor 21 Tahun 2008 tentang Perbankan Syariah pun lahir yang secara spesifik mengatur bagaimana perbankan dengan prinsip syariah bekerja di Indonesia. ${ }^{5}$ Selain sejumlah peraturan perundangan terkait perbankan syairiah, sebagaimana disebutkan di atas, perkembangan perbankan syariah di Indonesia juga didukung oleh otoritas keagamaan dalam hal ini Majelis Ulama Indonesia (MUI) yang secara aktif memberikan fatwafatwa hukum terkait aktivitas umat di bidang ini. Fatwa-fatwa hukum MUI ada kalanya bersumber dari Dewan Syariah Nasional yang memang bertugas secara khusus mendampingi industri perbankan syariah maupun dari MUI sendiri secara langsung sebagi jawaban atas berbagai persoalan umat.

Jumlah penduduk muslim di Indonesia yang besar dan juga dukungan perundangan maupun fatwa hukum Islam yang memadai, mau tidak mau membawa tuntutan bagi pengelola perbankan syariah untuk meningkatkan kualitas pelayanan keuangan berbasis nilai-nilai syariah. Tuntutan semacam ini

${ }^{3}$ Ibid.,, hal. 5 dan 31 .

${ }^{4}$ Ibid., hal. 6.

${ }^{5}$ Ibid., hal. 7. 
adalah wajar mengingat ekspektasi yang tinggi terhadap perbankan syariah juga dikaitkan dengan keyakinan transenden bahwa sistem inilah yang relevan dengan umat Islam demi mencapai kesejahteraan duniawi dan ukhrawi. Untuk itulah artikel ini dimaksudkan untuk menganalisa kerangka pengembangan perbankan syariah di Indonesia dan membandingkannya dengan capaian-capaian di bidang kinerja keuangan untuk melihat lebih kauh kontribusi industri yang berkembang pesat ini bagi pembangunan nasional.

\section{Kerangka Kerja Perbankan Syariah di Indonesia}

Perbankan syariah di Indonesia merupakan bagian integral dari pengembangan sebuah sistem perbankan nasional dalam kerangka Arsitektur Perbankan Indonesia (API). ${ }^{6}$ API pada dasarnya merupakan suatu kerangka dasar sistem perbankan Indonesia yang bersifat menyeluruh dan memberikan arah, bentuk, dan tatanan industri perbankan untuk rentang waktu lima sampai sepuluh tahun ke depan. ${ }^{7}$ Arah kebijakan pengembangan industri perbankan sebagaimana dirumuskan dalam API dilandasi oleh sebuah visi untuk mencapai sistem perbankan yang sehat, kuat dan efisien guna menciptakan kestabilan sistem keuangan dalam rangka membantu mendorong pertumbuhan ekonomi nasional. ${ }^{8}$

Bank Indonesia sejak 9 Januari 2004 telah meluncurkan API sebagai suatu kerangka menyeluruh arah kebijakan pengembangan industri perbankan Indonesia. Peluncuran API yang dilakukan otoritas moneter juga dalam kerangka tak terpisahkan dari upaya Pemerintah dan Bank Indonesia untuk membangun kembali perekonomian Indonesia melalui penerbitan buku putih Pemerintah sesuai dengan Inpres No. 5 Tahun 2003 yang menempatkan API sebagai salah satu program utamanya. ${ }^{9}$ API sendiri memiliki enam pilar utama sebagai penopang yaitu struktur perbankan yang sehat, sistem pengaturan yang efektif, sistem pengawasan yang independen dan efektif, industri perbankan yang kuat, infrastruktur pendukung yang mencukupi, dan perlindungan konsumen. ${ }^{10}$

Bank Indonesia juga telah melakukan sejumlah penyempurnaan terkait program-program kegiatan API sebagai konsekuensi dari perkembanganperkembangan yang terjadi pada perekonomian nasional maupun internasional. Penyempurnaan yang dilakukan terhadap program-program API tersebut antara lain adalah strategi-strategi lebih spesifik terkait pengembangan perbankan syariah,

${ }^{6}$ Muhammad Kamal Zubair (2008), "Akselerasi Pertumbuhan Bank Syariah di Indonesia” Millah Jurnal Studi Islam, Vol. III, No. 1, Agustus 2008, hal. 1-16.

${ }^{7}$ Bank Indonesia, Arsitektur Perbankan Indonesia, dikutip dari http://www.bi.go. id/web/id/Perbankan/Arsitektur+Perbankan+Indonesia/ pada 1 September 2009.

${ }^{8}$ Ibid.

${ }^{9}$ Ibid.

${ }^{10}$ Ibid. 
BPR, dan UMKM. Hal ini dilakukan agar API memiliki program kegiatan yang lebih lengkap dan komprehensif yang cakupannya termasuk sistem perbankan secara keseluruhan baik Bank umum dan BPR, baik yang beroperasi dengan sistem konvensional maupun syariah, dan juga pada pengembangan UMKM. ${ }^{11}$

Cetak biru yang secara spesifik diperuntukkan bagi perbankan syariah telah disusun dan menjadi arahan pengembangan sejak 2002 hingga 2011 mendatang. Biro Perbankan Syariah Bank Indonesia sejak tahun 2001 telah melakukan kajian dalam rangka menyusun cetak biru yang diharapkan dapat mempercepat kontribusi dan peranan aktif perbankan syariah di Indonesia ini. ${ }^{12}$ Visi yang akan dicapai dari pengembangan perbankan syariah sendiri dapat dirumuskan sebagai "Terwujudnya sistem perbankan syariah yang kompetitif, efisien, dan memenuhi prinsip kehati-hatian serta mampu mendukung sektor riil secara nyata melalui kegiatan pembiayaan berbasis bagi hasil dan transaksi riil dalam kerangka keadilan, tolong menolong dan menuju kebaikan guna mencapai kemaslahatan masyarakat". ${ }^{13}$

Visi di atas, sebagaimana dijelaskan dalam Gambar 1 berikut, disusun berdasarkan nilai-nilai dasar dari perspektif makro maupun mikro. Visi dan misi yang dibentuk, kemudian bersama-sama dengan kondisi aktual diarahkan untuk mencapai sejumlah sasaran, yaitu istiqomah dalam memenuhi prinsip Syariah, menerapkan prinsip kehati-hatian dan good corporate governance, berdaya saing dan efisien, dan mendukung kestabilan sistem perbankan dan memberikan manfaat yang luas. Sasaran-sasaran ini kemudian diarahkan untuk langkah praktis berupa inisiatif-inisiatif yang disusun berdasarkan paradigma kebijakan yang memperhatikan mekanisme pasar, prinsip kesetaraan, pendekatan bertahap dan berkesinambungan, dan patuh terhadap prinsip syariah.

${ }^{11}$ Ibid.

12 Bank Indonesia (2002), Cetak Biru Pengembangan Perbankan Syariah Indonesia, (Jakarta: Direktorat Perbankan Syariah Bank Indonesia), hal. i.

${ }^{13}$ Ibid. 
Gambar 1 Kerangka Pengembangan Visi, Misi, Sasaran, dan Inisiatif Cetak Biru Perbankan Indonesia

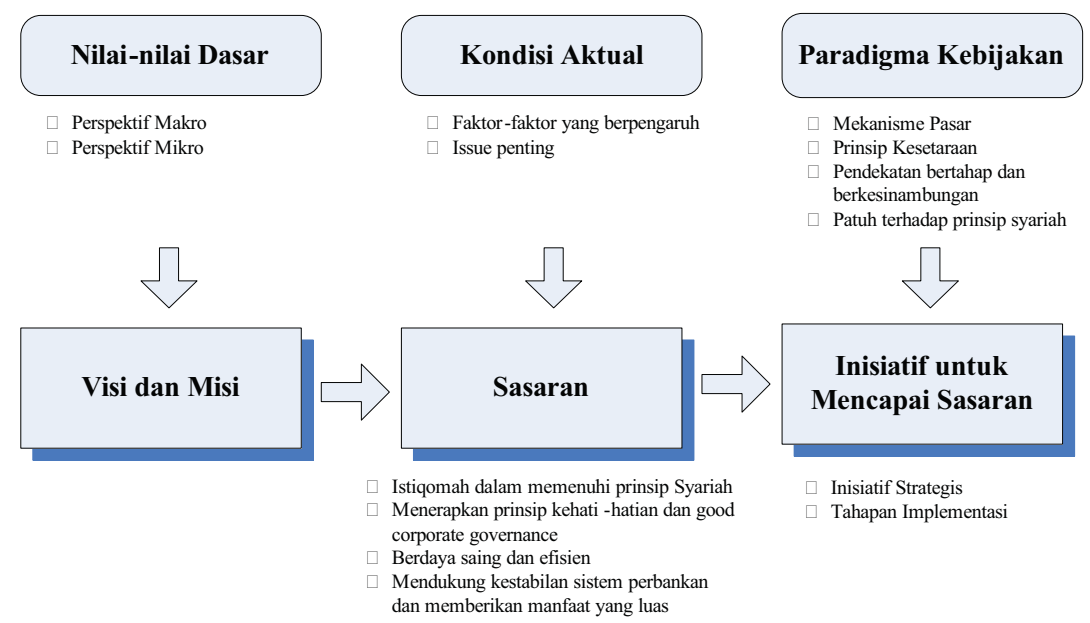

Sumber: Bank Indonesia (2002), Cetak Biru Pengembangan Perbankan Syariah Indonesia (Jakarta: Direktorat Perbankan Syariah Bank Indonesia), hal. 16.

Inisiatif-inisiatif yang dirumuskan pada hakikatnya merupakan langkah praktis penerjemahan sasaran dan dibingkai dalam paradigma kebijakan sebagaimana disebutkan di atas yang dinilai penting oleh Bank Indonesia dan juga stakeholder lainnya. Inisiatif-inisiatif yang diambil secara umum diarahkan untuk mencapai sasaran dalam tiga tahap, yaitu tahap pertama antara tahun 2002-2004, tahap kedua antara 2004-2008, dan tahap ketiga antara 2008-2011.14 Tabel 1 berikut merangkum tahapan implementasi dan prioritas inisiatif dalam cetak biru pengembangan perbankan syariah di Indonesia.

\footnotetext{
${ }^{14}$ Ibid.
} 


\section{Tabel 1 Tahap Implementasi dan Prioritas Inisiatif-inisiatif Cetak Biru Perbankan Syariab}

\begin{tabular}{|c|c|c|c|}
\hline & $\begin{array}{c}\text { Meletakkan landasan } \\
\text { pengembangan } \\
\text { yang kuat bagi } \\
\text { pertumbuhan }\end{array}$ & $\begin{array}{c}\text { Memperkuat struktur } \\
\text { industri perbankan } \\
\text { syariah }\end{array}$ & $\begin{array}{c}\text { Memenuhi standar } \\
\text { keuangan dan } \\
\text { kualitas pelayanan } \\
\text { internasional } \\
\end{array}$ \\
\hline & $\begin{array}{c}\text { Tahap I } \\
(2002-2004) \\
\end{array}$ & $\begin{array}{c}\text { Tahap II } \\
2004-2008) \\
\end{array}$ & $\begin{array}{c}\text { Tahap III } \\
(2008-2011) \\
\end{array}$ \\
\hline $\begin{array}{l}\text { Kepatuhan } \\
\text { kepada prinsip } \\
\text { syariah }\end{array}$ & \begin{tabular}{|l} 
Meningkatkan \\
pemahaman konsep \\
keuangan syariah \\
. Menyusun norma- \\
norma keuangan \\
syariah \\
. Melakukan kajian \\
tentang mekanisme \\
dan sistem \\
pengaturan dan \\
pengawasan yang \\
terintegrasi
\end{tabular} & $\begin{array}{l}\text { Mendorong } \\
\text { peningkatan } \\
\text { efektifitas } \\
\text { pengawasan } \\
\text { Mengembangkan } \\
\text { konsep insentif } \\
\text { kepatuhan pada } \\
\text { prinsip syariah }\end{array}$ & $\begin{array}{l}\text { Mewujudkan konsep } \\
\text { rating yang terintegrasi } \\
\text { antara sisi syariah dan } \\
\text { keuangan }\end{array}$ \\
\hline $\begin{array}{l}\text { Ketentuan } \\
\text { kehati-hatian }\end{array}$ & \begin{tabular}{|l} 
Menyempurnakan \\
ketentuan kehati- \\
hatian dan good \\
corporate governance \\
berdasarkan \\
karakteristik \\
operasional bank \\
syariah \\
. Menyempurnakan \\
ketentuan jaringan \\
kantor \\
. Mengkaji mekanisme \\
umpan balik dalam \\
disain pengaturan \\
dan pengawasan \\
Mengkaji penerapan \\
real-time supervision
\end{tabular} & $\begin{array}{l}\text { Mengembangkan } \\
\text { kerangka pengaturan } \\
\text { dan pengawasan } \\
\text { berbasis risiko } \\
\text { Mengembangkan } \\
\text { konsep pengaturan } \\
\text { bagi kebijakan exit } \\
\text { dan } \text { entry } \\
\text { Menerapkan real- } \\
\text { time supervision }\end{array}$ & $\begin{array}{l}\text { Mendorong terciptanya } \\
\text { self-regulatory system }\end{array}$ \\
\hline $\begin{array}{l}\text { Efisiensi operasi } \\
\text { dan daya saing }\end{array}$ & $\begin{array}{l}\text {. Mendorong } \\
\text { tercapainya economies } \\
\text { of scale dan economies } \\
\text { of scope } \\
\text {. Meningkatkan } \\
\text { kualitas SDI } \\
\text {. Melakukan kerjasama } \\
\text { dengan lembaga } \\
\text { terkait } \\
\text {. Mendorong } \\
\text { peningkatan } \\
\text { efektivitas fungsi } \\
\text { dan peran arbitrase } \\
\text { syariah }\end{array}$ & $\begin{array}{l}\text { Mendorong aliansi } \\
\text { strategis } \\
\text { Mewujudkan } \\
\text { kerjasama bagi } \\
\text { pembinaan dengan } \\
\text { lembaga terkait }\end{array}$ & $\begin{array}{l}\text { Mendorong terciptanya } \\
\text { pemain berskala global } \\
\text { dan berdaya saing } \\
\text { internasional }\end{array}$ \\
\hline
\end{tabular}




\begin{tabular}{|c|c|c|c|}
\hline & $\begin{array}{c}\text { Meletakkan landasan } \\
\text { pengembangan } \\
\text { yang kuat bagi } \\
\text { pertumbuhan }\end{array}$ & $\begin{array}{c}\text { Memperkuat struktur } \\
\text { industri perbankan } \\
\text { syariah }\end{array}$ & $\begin{array}{l}\text { Memenuhi standar } \\
\text { keuangan dan } \\
\text { kualitas pelayanan } \\
\text { internasional }\end{array}$ \\
\hline & $\begin{array}{c}\text { Tahap I } \\
(2002-2004) \\
\end{array}$ & $\begin{array}{c}\text { Tahap II } \\
2004-2008) \\
\end{array}$ & $\begin{array}{c}\text { Tahap III } \\
(2008-2011) \\
\end{array}$ \\
\hline $\begin{array}{l}\text { Kestabilan } \\
\text { sistem dan } \\
\text { kemanfaatan } \\
\text { bagi } \\
\text { perekonomian }\end{array}$ & $\begin{array}{l}\text { Mendukung } \\
\text { terbentuknya } \\
\text { forum komunikasi } \\
\text { pengembangan } \\
\text { perbankan syariah } \\
\text { Melakukan kajian } \\
\text { awal mengenai } \\
\text { potensi systemic cost } \\
\text { Melakukan kajian } \\
\text { tentang penerapan } \\
\text { dan manfaat konsep } \\
\text { bagi hasil }\end{array}$ & $\begin{array}{l}\text { Mendorong aktifnya } \\
\text { forum informasi dan } \\
\text { kajian perbankan } \\
\text { syariah } \\
\text {. Mendorong } \\
\text { terlibatnya lembaga } \\
\text { rating dalam } \\
\text { kegiatan perbankan } \\
\text { - Menyusun konsep } \\
\text { deposit takaful yang } \\
\text { dapat meminimalkan } \\
\text { potensi systemic cost } \\
\text { - Melakukan kajian } \\
\text { voluntary sector } \\
\text { Mendorong } \\
\text { peningkatan peranan } \\
\text { pembiayaan bagi } \\
\text { hasil }\end{array}$ & $\begin{array}{l}\text { Mendorong } \\
\text { terwujudnya konsep } \\
\text { operasi perbankan/ } \\
\text { keuangan syariah yang } \\
\text { terintegrasi (kaffah) }\end{array}$ \\
\hline
\end{tabular}

Sumber: Bank Indonesia (2002), Cetak Biru Pengembangan Perbankan Syariah Indonesia (Jakarta: Direktorat Perbankan Syariah Bank Indonesia), hal. 21.

Tahun 2009 ini merupakan bagian dari tahapan ketiga atau tahapan terakhir yang tema pokoknya adalah memenuhi standar keuangan dan kualitas pelayanan internasional. Pada tahap ini, inisiatif kepatuhan kepada prinsip syariah diarahkan untuk mewujudkan konsep rating yang terintegrasi antara sisi syariah dan keuangan. Bank Indonesia pada tahapan ini mendorong diterapkannya konsep pengaturan yang terintegrasi antara aspek keuangan dan kesyariahan seiring dengan prinsip kesatuan diatara keduanya. Adapun untuk ketentuan kehati-hatian, Bank Indonesia mendorong terciptanya self-regulatory system. Untuk mencapai ke arah tersebut dan sesuai dengan paradigma pengaturan perbankan moderen, Bank Indonesia mendorong diberlakukannya sistem pengaturan yang berbasis insentif. Tujuan akhir dari paradigma ini adalah self-regulatory banking system, yang meniscayakan kemandirian bank syariah dalam mengatur sendiri kelembagaannya. ${ }^{15}$

Sementara itu, pada sasaran efisiensi operasi dan daya saing, Bank Indonesia mendorong terciptanya pemain berskala global dan berdaya saing internasional melalui konsistensi dalam mendorong efisiensi operasi. Pada aspek kestabilan sistem dan kemanfaatan bagi perekonomian, pada tahap terakhir ini Bank Indonesia mendorong perbankan syariah untuk mewujudkan konsep operasi

\footnotetext{
${ }^{15}$ Ibid. hal. 26.
} 
perbankan/keuangan syariah yang terintegrasi (kaffah). Sistem ini diharapkan dapat menggunakan sumber-sumber dana yang diatur dalam syariah dan skaligus menggunakannya sesuai dengan syariah serta amanah (konsep safety net) dalam pelaksanaan operasinya. ${ }^{16}$

\section{Kinerja Keuangan Perbankan Syariah di Indonesia dan Kontribusinya bagi Pembangunan Nasional}

Secara umum perkembangan kinerja keuangan perbankan syariah di Indonesia dapat diringkas pada Tabel 2 berikut. Data-data yang ada menunjukkan bahwa perbankan syariah mampu terus bertumbuh baik dalam sisi aset, perolehan laba maupun pengumpulan dana pihak ketiga. Sepanjang 2002 hingga September 2009, aset perbankan syariah tumbuh dari Rp4.045 Miliyar menjadi Rp58.034 Miliyar. Jumlah ini menunjukkan pertumbuhan positif setiap tahunnya yang bahkan mencapai 90\% lebih pada 2003 dan 2004. Sedangkan untuk tahun selanjutnya pertumbuhan berkisar di antara $17 \%$ hingga $36 \%$ per tahun.

Tabel 2 Perkembangan Aset, Laba Tabun Berjalan, dan DPK Perbankan Syariab 2002-2009 dalam Miliyar Rupiab

\begin{tabular}{|l|r|r|r|r|r|r|r|r|}
\hline \multicolumn{1}{|c|}{ Indikator } & $\mathbf{2 0 0 2}$ & $\mathbf{2 0 0 3}$ & $\mathbf{2 0 0 4}$ & $\mathbf{2 0 0 5}$ & $\mathbf{2 0 0 6}$ & \multicolumn{2}{c|}{$\mathbf{2 0 0 7}$} & \multicolumn{2}{c|}{$\mathbf{2 0 0 8}$} & \multicolumn{1}{c|}{$\mathbf{2 0 0 9}$} \\
\hline Aset & 4.045 & 7.859 & 15.326 & 20.880 & 26.722 & 36.538 & 49.555 & 58.034 \\
\hline Pertumbuhan (\%) & & 94,28 & 95,01 & 36,24 & 27,98 & 36,73 & 35,63 & 17,11 \\
\hline Laba Tahun Berjalan & 54 & 43 & 162 & 298 & 414 & 628 & 605 & 558 \\
\hline Pertumbuhan (\%) & & $-21,07$ & 280,58 & 83,54 & 38,93 & 51,69 & $-3,66$ & $-7,77$ \\
\hline DPK & 2.918 & 5.725 & 11.862 & 15.584 & 20.672 & 28.012 & 36.852 & 45.381 \\
\hline Pertumbuhan (\%) & & 96,21 & 107,20 & 31,38 & 32,65 & 35,51 & 31,56 & 23,14 \\
\hline
\end{tabular}

Sumber: Bank Indonesia (2009), Statistik Perbankan Syariah September 2009 (Jakarta: Direktorat Perbankan Syariah Bank Indonesia), Tabel 5, hal.5.

Catatan: Keterangan: 2002, 2003, 2004, dan 2005 disesuaikan dari data yang sebelumnya dalam juta rupiah. Data per Desember untuk setiap tahun kecuali data 2009 merupakan data per September.

Pertumbuhan pesat dalam aset perbankan syariah ini mengindikasikan bahwa sejumlah paket kebijakan pemerintah dan juga lembaga terkait relatif mampu meningkatkan kesadaran masyarakat muslim Indonesia untuk terlibat aktif dalam industri perbankan syariah. Namun demikian, di sisi lain pertumbuhan yang terus berlanjut masih memerlukan akselerasi mengingat sampai dengan September 2009 aset perbankan syariah baru berada pada angka Rp58.034 Miliyar atau kalah jauh dari aset perbankan umum yang secara nasional berada

${ }^{16}$ Ibid. 
pada angka Rp2.388.616 Miliyar. ${ }^{17}$ Dengan perbandingan ini, aset perbankan syariah dapat dianggap belum signifikan jika dibandingkan dengan aset perbankan nasional secara keseluruhan. Hal ini mengindikasikan perlunya lagi peningkatan akselerasi baik dari sisi pengambil kebijakan maupun pelaku usaha dalam industri perbankan syariah karena bagaimanapun keandalan perbankan ini dalam menjaga stabilitas ekonomi di saat krisis amat membantu perekonomian.

Selain perkembangan aset, perbankan syariah selama 2002 hingga September 2009 ini juga mencatatkan prestasi dalam meraih keuntungan yang ditandai dengan positifnya laba tahun berjalan. Laba tahun berjalan yang diperoleh perbankan syariah secara nasional senantiasa meningkat kecuali untuk September 2009 yang belum merupakan akhir perhitungan. Jika dilihat dari sisi pertumbuhan keuntungan, laba ini senantiasa meningkat sejak 2004 hingga 2007 dan mulai menurun ke pertumbuhan negatif pada 2008 dan 2009. Namun demikian, nilainya secara nominal masih sangat signifikan bagi sebuah industri perbankan, yaitu mencapai di atas Rp600 Miliyar selama dua tahun terakhir. Hal ini menyiratkan bahwa secara ekonomis, usaha di industri ini masih sangat menguntungkan sehingga terbuka kesempatan bagi pelaku usaha baik dalam maupun luar negeri untuk ikut serta dalam proses akselerasi perbankan syariah.

Perkembangan dana pihak ketiga di perbankan syariah juga menunjukkan peningkatan pada data yang ada. Dari sejumlah Rp2.918 Miliyar pada 2002, dana pihak ketiga naik menjadi Rp45.381 Miliyar pada September 2009. Setiap tahunnua, pertumbuhannya senantiasa positif bahkan mencapai $96,21 \%$ dan $107,20 \%$ pada 2003 dan 2004. Tingginya pertumbuhan pada dua tahun ini, patut diduga merupakan buah dari Fatwa MUI tentang pengharaman bunga bank pada Desember 2003. Fatwa ini memang diharapkan pada saat tersebut mampu mendongkrak akselerasi perbankan syariah di Indonesia dan terbukti dampaknya pun dirasakan perbankan konvensional. Penelitian dengan model CAMEL Modified pada data dari Januari 2002 hingga Desember 2005 menunjukkan bahwa trend perkembangan kinerja keuangan perbankan nasional setelah fatwa MUI cenderung mengalami peningkatan. Enam dari tujuh rasio keuangan secara statistik menunjukkan perubahan yang signifikan. ${ }^{18}$ Secara keseluruhan, dana pihak ketiga bahkan mampu tumbuh lebih dari $20 \%$ setiap tahunnya yang menunjukkan makin tingginya kepercayaan masyarakat terhadap pelaku industri ini. Hal ini sekaligus menjadikan tantangan bagi perbankan syariah untuk mampu meningkatkan kualitas pelayanan karena tuntutan persaingan yang lebih besar dari masa sebelumnya.

${ }^{17}$ Bank Indonesia (2009), Statistik Perbankan Indonesia, Vol. 7, No. 10, September 2009 (Jakarta: Direktorat Perizinan dan Informasi Perbankan Bank Indonesia), hal. 2.

${ }^{18}$ Yuli Andriansyah (2006), "Kinerja Keuangan Perbankan Nasional sebelum dan sesudah Fatwa MUI", Laporan Penelitian Mahasiswa dengan Pendanaan Departemen Agama RI, tidak dipublikasikan. 
Perkembangan aset, laba, dan dana pihak ketiga pada perbankan syariah sebagaimana dijelaskan diatas juga didukung dengan kemampuan perbankan syariah untuk menjaga stabilitas pembiayaan. Dari data yang ada, pembiayaan yang diberikan perbankan syariah sebagian besar masuk dalam kategori lancar sebagaimana ditampilkan dalam Tabel 3 berikut. Pada 2001, dari total Rp2.050 Miliyar pembiayaan yang dikeluarkan perbankan syariah, Rp1.843 Miliyar diantaranya berada dalam kondisi lancar. Catatan ini masih terus dipertahankan hingga data September 2009 yang menunjukkan dari total Rp44.523 Miliyar dana pembiayaan perbankan syariah, Rp38.815 Miliyar diantaranya dalam kondisi lancar.

Tabel 3 Perkembangan Pembiayaan Perbankan Syariab, 2001-2009 dalam Miliyar Rupiab

\begin{tabular}{|l|r|r|r|r|r|r|r|r|r|}
\hline \multicolumn{1}{|c|}{ Indikator } & $\mathbf{2 0 0 1}$ & $\mathbf{2 0 0 2}$ & $\mathbf{2 0 0 3}$ & $\mathbf{2 0 0 4}$ & $\mathbf{2 0 0 5}$ & $\mathbf{2 0 0 6}$ & $\mathbf{2 0 0 7}$ & $\mathbf{2 0 0 8}$ & $\mathbf{2 0 0 9}$ \\
\hline Pembiayaan & 2.050 & 3.277 & 5.530 & 11.324 & 15.232 & 20.445 & 27.944 & 38.195 & 44.523 \\
\hline a. Lancar & 1.843 & 3.022 & 5.149 & 10.650 & 14.027 & 18.583 & 25.494 & 35.076 & 38.815 \\
\hline $\begin{array}{l}\text { b. Dalam } \\
\text { Perhatian } \\
\text { Khusus }\end{array}$ & 124 & 119 & 252 & 405 & 776 & 891 & 1.319 & 1.610 & 3.161 \\
\hline c. Kurang Lancar & 54 & 51 & 58 & 122 & 201 & 353 & 321 & 525 & 1136 \\
\hline d. Diragukan & 7 & 30 & 16 & 66 & 73 & 236 & 267 & 224 & 341 \\
\hline e. Macet & 21 & 53 & 56 & 81 & 155 & 383 & 543 & 759 & 1,070 \\
\hline $\begin{array}{l}\text { Non Performing } \\
\text { Loan (Nominal) }\end{array}$ & 82 & 135 & 130 & 269 & 429 & 971 & 1.131 & 1.509 & 2.547 \\
\hline $\begin{array}{l}\text { Rasio Non } \\
\text { Performing Loan } \\
\text { (\%) }\end{array}$ & 4,01 & 4,12 & 2,34 & 2,37 & 2,82 & 4,75 & 4,05 & 3,95 & 5,72 \\
\hline
\end{tabular}

Sumber : Bank Indonesia (2006), Statistik Perbankan Indonesia, Vol. 4, No. 7, Juni 2006 (Jakarta: Direktorat Perizinan dan Informasi Perbankan Bank Indonesia0, Tabel 2.5, hal. 82 dan Bank Indonesia (2009), Statistik Perbankan Indonesia, Vol. 7, No. 10, September 2009 (Jakarta: Direktorat Perizinan dan Informasi Perbankan Bank Indonesia), Tabel 2.5, hal. 96.

Catatan: Data per Desember untuk setiap tahun kecuali data 2009 merupakan data per September.

Kemampuan perbankan syariah untuk mempertahankan kinerja positif dalam pembiayaan ini membuat Non Performing Finance (NPF) atau Non Performing Loan (NPL) pada perbankan konvensional berada pada kisaran aman, yaitu dibawah 5\% untuk data 2001 hingga 2008. Hal ini membuktikan bahwa secara alamiah pengelolaan pembiayaan pada perbankan syariah berjalan sehat dan mampu membantu menjaga stabilitas keuangan nasional. Adapun untuk komposisi pembiayaan yang diberikan perbankan syariah berdasarkan akad-akad yang ada dirangkum data dan perkembangannya antara tahun 2005 hingga September 2009 pada Tabel 4 berikut. Secara agregat, pembiayaan yang diberikan 
perbankan syariah menunjukkan trend peningkatan dari Rp15.232 Miliyar pada 2005 hingga mencapai Rp44,523 Miliyar pada September 2009.

Tabel 4 Komposisi Pembiayaan yang diberikan Bank Umum Syariab dan Unit Usaba Syariah, 2005-2009 dalam Miliyar Rupiab

\begin{tabular}{|l|r|r|r|r|r|r|}
\hline \multicolumn{1}{|c|}{ Akad Pembiayaan } & \multicolumn{1}{c|}{$\mathbf{2 0 0 5}$} & \multicolumn{1}{c|}{$\mathbf{2 0 0 6}$} & \multicolumn{1}{c|}{$\mathbf{2 0 0 7}$} & \multicolumn{1}{c|}{$\mathbf{2 0 0 8}$} & \multicolumn{1}{c|}{$\mathbf{2 0 0 9}$} & \multicolumn{1}{c|}{ Rerata } \\
\hline Akad Mudharabah & 3,124 & 4,062 & 5,578 & 6,205 & 10,007 & 5,795 \\
\hline Kontribusi (\%) & 20.51 & 19.87 & 19.96 & 16.25 & 22.48 & 19.80 \\
\hline Akad Musyarakah & 1,898 & 2,335 & 4,406 & 7,411 & 6,459 & 4,502 \\
\hline Kontribusi (\%) & 12.46 & 11.42 & 15.77 & 19.40 & 14.51 & 15.38 \\
\hline Akad Murabahah & 9,487 & 12,624 & 16,553 & 22,486 & 25,046 & 17,239 \\
\hline Kontribusi (\%) & 62.28 & 61.75 & 59.24 & 58.87 & 56.25 & 58.90 \\
\hline Akad Salam & 0 & 0 & 0 & 0 & 0 & 0 \\
\hline Kontribusi (\%) & 0.00 & 0.00 & 0.00 & 0.00 & 0.00 & 0.00 \\
\hline Akad Istishna & 282 & 337 & 351 & 369 & 415 & 351 \\
\hline Kontribusi (\%) & 1.85 & 1.65 & 1.26 & 0.97 & 0.93 & 1.20 \\
\hline Akad Ijarah & 316 & 836 & 516 & 765 & 1,195 & 726 \\
\hline Kontribusi (\%) & 2.07 & 4.09 & 1.85 & 2.00 & 2.68 & 2.48 \\
\hline Akad Qardh & 125 & 250 & 540 & 959 & 1,400 & 655 \\
\hline Kontribusi (\%) & 0.82 & 1.22 & 1.93 & 2.51 & 3.14 & 2.24 \\
\hline Lainnya & 0 & 0 & 0 & 0 & 0 & 0 \\
\hline Total & 15,232 & 20,445 & 27,944 & 38,195 & 44,523 & 29,268 \\
\hline
\end{tabular}

Sumber: Statistik Perbankan Syariah September 2009, Tabel 15, hal. 15.

Catatan: Data per Desember untuk setiap tahun kecuali data 2009 merupakan data per September. Kontribusi menunjukkan prosentase terhadap total pembiayaan, data merupakan hasil estimasi penulis.

Secara agregatif, setiap tahunnya perbankan syariah menyalurkan pembiayaan sebesar Rp29,268 Miliyar setiap tahun antara 2005 hingga September 2009. Dari total pembiayaan, akad murabahah masih mendominasi, yaitu rata-rata sekitar 58,90\% setiap tahunnya. Akad murabahah per definisi adalah "perjanjian pembiayaan berupa transaksi jual beli suatu barang sebesar harga perolehan barang ditambah dengan margin yang disepakati oleh para pihak, dimana penjual menginformasikan terlebih dahulu harga perolehan kepada pembeli". ${ }^{19}$ Dominasi pembiayaan perbankan syariah pada akad murabahah menimbulkan kritik tajam dari aspek hukum Islam. Hal ini terjadi mengingat akad

${ }_{19}$ Bank Indonesia (2009), Statistik Perbankan Syariah September 2009 (Jakarta: Direktorat Perbankan Syariah Bank Indonesia), hal. vii. 
ini, menurut sebagian ulama bukan merupakan akad jual beli melainkan hilah untuk mengambil riba. Ada pula yang menganggap bahwa akad ini merupakan contoh dari bay' al-ma'dûm atau jual beli yang tidak ada objeknya. Pendapat lain menyebut akad ini sebagai bay'atani fi al-bay'ah atau dua kali akad jual beli pada satu barang. ${ }^{20}$

Terdapat sejumlah alasan mengapa perbankan syariah begitu dominan dalam menyalurkan pembiayaan pada akad murabahah, yaitu pertama murabahah merupakan bentuk investasi jangka pendek yang lebih menguntungkan bagi perbankan jika dibandingkan misalnya dengan akad mudharabah atau profit and loss sharing, kedua penentuan harga barang dalam akad murabahah memungkinkan terjaminnya pengembalian aset perbankan syariah; ketiga resiko ketidakpastian bisnis dalam akad murabahah dapat lebih diminimalkan dibandingkan bila akad mudharabah yang diberlakukan; dan keempat akad murabahah juga lebih menguntungkan bagi nasabah karena hubungan nasabah dan bank adalah kreditur dan debitur, bukan rekan kerja sebagaimana dalam akad mudharabah. ${ }^{21}$

Akad murabahah juga dinilai mirip dengan jenis kredit konsumtif yang biasa ditawarkan oleh perbankan konvensional sehingga masyarakat telah terbiasa dengan akad sejenis ini. Selain keempat faktor di atas, terdapat sejumlah faktor yang secara kuantitatif mempengaruhi tinggi rendahnya permintaan masyarakat terhadap pembiayaan murabahah pada perbankan syariah. Faktor-faktor tersebut antara lain adalah margin murabahah, bunga kredit bank konvensional, inflasi, kurs, akses masyarakat, dan nilai jaminan. ${ }^{22}$ Dengan demikian, perilaku masyarakat terhadap akad murabahah pada perbankan syariah seolah merupakan substitusi atau kompetitor dari kredit konsumtif pada perbankan konvensional.

Kontribusi terbesar kedua secara rata-rata lima tahun terakhir dalam pembiayaan perbankan syariah adalah akad mudharabah. Pengertian akad mudharabah adalah "perjanjian pembiayaan/ penanaman dana dari pemilik dana (shahibul maal) kepada pengelola dana (mudharib) untuk melakukan kegiatan usaha tertentu yang sesuai syariah, dengan pembagian hasil usaha antara kedua belah pihak berdasarkan nisbah yang telah disepakati sebelumnya" ${ }^{23}$ Pembiayaan berdasarkan akad ini meningkat dari Rp 3.124 Miliyar pada 2005 menjadi Rp 10.007 Miliyar pada September 2009. Rata-rata kontribusinya selama lima tahun terakhir mencapai 19,80\% dari total pembiayaan perbankan syariah.

Akad musyarakah selanjutnya menjadi kontributor terbesar ketiga dalam pembiayaan pada perbankan syariah dengan rata-rata selama lima tahun terakhir

${ }^{20}$ Alfitri (2002), "Evaluasi Perkembangan Perbankan Islam di Indonesia”, Hermenia, Jurnal Kajian Islam Interdisipliner, Vol. 1, No. 1, Januari-Juni 2002, hal. 1-26.

${ }^{21}$ Ibid.

22 Perdana Wahyu Santosa (2009), "Faktor-faktor yang Mempengaruhi Permintaan Pembiayaan Murabahah Bank Syariah di Indonesia (Periode Januari 2004 - Desember 2008)", Dikta Ekonomi Volume 6 Nomor 2, Agustus 09 / Rajab 1430 H, hal. 101-112.

${ }^{23}$ Bank Indonesia (2009), Statistik Perbankan Syariah September 2009, hal. vii. 
sebesar 15,38\%. Akad ini mencakup pembiayaan sebesar Rp 1.898 Miliyar pada 2005 dan terus berkembang hingga mencapai Rp 6.459 Miliyar pada September 2009. Sementara itu, akad-akad lainnya yaitu akad ijarah, akad qardh, dan akad istishna' masing-masing menyumbang kurang dari 3\% secara rata-rata dalam lima tahun terakhir. Akad lainnya, yaitu akad salam sampai dengan September 2009 belum digunakan oleh perbankan syariah untuk menyalurkan pembiayaan. Hal ini tentunya layak mendapat perhatian, mengingat akad salam berpotensi besar bagi upaya pengembangan sektor industri kecil melalui pembiayaan perbankan syariah.

Komposisi pembiayaan yang disalurkan melalui perbankan syariah dapat pula dilihat dari sektor ekonominya, sebagaimana ditampilkan dalam Tabel 4 berikut ini. Dari data yang ada, diketahui bahwa rata-rata tertinggi untuk pembiayaan perbankan syariah lima tahun terakhir ada pada sektor jasa dunia usaha, yaitu kurang lebih sebesar Rp 8.696 Miliyar atau 29,71\%. Pembiayaan untuk sektor ini tumbuh dari Rp 4.504 Miliyar pada 2005 menjadi Rp13.334 Miliyar pada September 2009. Kontribusi terbesar selanjutnya diberikan oleh sektor lain-lain atau sektor selain sembilan sektor ekonomi dan sektor perdagangan, restoran dan hotel. Sektor lain-lain menyumbang rata-rata 25,26\% setiap tahun dan sektor perdagangan, restoran dan hotel menyumbang rata-rata $12,78 \%$.

Tabel 5 Komposisi Pembiayaan yang diberikan Bank Umum Syariab dan Unit Usaba Syariah berdasarkan Sektor Ekonomi, 2005-2009 dalam Miliyar Rupiab

\begin{tabular}{|l|r|r|r|r|r|r|}
\hline \multicolumn{1}{|c|}{ Sektor Ekonomi } & $\mathbf{2 0 0 5}$ & $\mathbf{2 0 0 6}$ & $\mathbf{2 0 0 7}$ & $\mathbf{2 0 0 8}$ & $\mathbf{2 0 0 9}$ & Rerata \\
\hline $\begin{array}{l}\text { Pertanian, kehutanan dan sarana } \\
\text { pertanian }\end{array}$ & 687 & 701 & 837 & 1.177 & 1.288 & 938 \\
\hline Kontribusi (\%) & 4,51 & 3,43 & 3,00 & 3,08 & 2,89 & 3,20 \\
\hline Pertambangan & 395 & 375 & 511 & 965 & 998 & 649 \\
\hline Kontribusi (\%) & 2,59 & 1,83 & 1,83 & 2,53 & 2,24 & 2,22 \\
\hline Perindustrian & 933 & 940 & 1.371 & 1.340 & 1.477 & 1.212 \\
\hline Kontribusi (\%) & 6,13 & 4,60 & 4,91 & 3,51 & 3,32 & 4,14 \\
\hline Listrik, gas dan air & 66 & 17 & 166 & 248 & 591 & 217 \\
\hline Kontribusi (\%) & 0,43 & 0,08 & 0,59 & 0,65 & 1,33 & 0,74 \\
\hline Konstruksi & 1.548 & 1.637 & 2.371 & 3.368 & 3.705 & 2.526 \\
\hline Kontribusi (\%) & 10,16 & 8,01 & 8,48 & 8,82 & 8,32 & 8,63 \\
\hline Perdagangan, restoran dan hotel & 1.716 & 3.041 & 4.152 & 4.426 & 5.370 & 3.741 \\
\hline Kontribusi (\%) & 11,27 & 14.87 & 14,86 & 11,59 & 12,06 & 12,78 \\
\hline $\begin{array}{l}\text { Pengangkutan, pergudangan dan } \\
\text { komunikasi }\end{array}$ & 1.261 & 1.165 & 1.569 & 2.759 & 3.080 & 1.967 \\
\hline Kontribusi (\%) & 8,28 & 5,70 & 5,61 & 7,22 & 6,92 & 6,72 \\
\hline
\end{tabular}


Yuli Andriansyah: Kinerja Keuangan ...

\begin{tabular}{|c|c|c|c|c|c|c|}
\hline Sektor Ekonomi & 2005 & 2006 & 2007 & 2008 & 2009 & Rerata \\
\hline Jasa dunia usaha & 4.504 & 5.458 & 8.425 & 11.757 & 13.334 & 8.696 \\
\hline Kontribusi (\%) & 29,57 & 26,70 & 30,15 & 30,78 & 29,95 & 29,71 \\
\hline Jasa sosial /masyarakat & 1.208 & 1.456 & 1.904 & 2.463 & 2.616 & 1.929 \\
\hline Kontribusi (\%) & 7,93 & 7,12 & 6,81 & 6,45 & 5,88 & 6,59 \\
\hline Lain-lain & 2.913 & 5.655 & 6.639 & 9.693 & 12.063 & 7.393 \\
\hline Kontribusi (\%) & 19,12 & 27,66 & 23,76 & 25,38 & 27,09 & 25,26 \\
\hline Total & 15.232 & 20.445 & 27.944 & 38.195 & 44.523 & 29.268 \\
\hline
\end{tabular}

Sumber: Bank Indonesia (2009), Statistik Perbankan Syariah September 2009 (Jakarta: Direktorat Perbankan Syariah Bank Indonesia), Tabel 17, hal. 17.

Catatan: Data per Desember untuk setiap tahun kecuali data 2009 merupakan data per September. Kontribusi menunjukkan prosentase terhadap total pembiayaan, hasil olahan penulis.

Sementara itu, sektor ekonomi lainnya hanya memiliki kontribusi ratarata kurang dari $10 \%$ setiap tahunnya. Kondisi ini mengindikasikan kontribusi pembiayaan perbankan syariah masih dominan di sektor non primer, terbukti dari sumbangan terhadap pertanian, kehutanan, dan usaha pertanian yang masih minim yaitu rata-rata 3,20\% per tahun. Rendahnya pembiayaan syariah pada sektor ini juga menandakan masih lemahnya komitmen perbankan syariah pada sektor yang menjadi tulang punggung bagi sebagian besar rakyat Indonesia.

Kontribusi perbankan syariah terhadap pembangunan nasional antara lain juga dapat dilihat dari rasio-rasio keuangan bank umum syariah dan unit usaha syariah sebagaimana ditunjukkan pada Tabel 5 berikut. Dari beberapa rasio yang ada, rasio Financing to Deposit Ratio (FDR) atau Loan to Deposit Ratio (LDR) bagi perbankan konvensional dapat dijadikan ukuran penting. FDR atau rasio pembiayaan terhadap dana pihak ketiga pada perbankan syariah selama lima tahun terakhir berada pada rata-rata 99,63\% yang menunjukkan bahwa perbankan syariah aktif menyalurkan dana kepada masyarakat. 


\section{Tabel 6 Rasio Keuangan Bank Umum Syariah dan Unit Usaba Syariah, 2005-2009}

\begin{tabular}{|l|r|r|r|r|r|r|}
\hline \multicolumn{1}{|c|}{ Rasio } & \multicolumn{1}{c|}{$\mathbf{2 0 0 5}$} & \multicolumn{1}{c|}{$\mathbf{2 0 0 6}$} & \multicolumn{1}{c|}{$\mathbf{2 0 0 7}$} & \multicolumn{1}{c|}{$\mathbf{2 0 0 8}$} & \multicolumn{1}{c|}{$\mathbf{2 0 0 9}$} & \multicolumn{1}{c|}{ Rerata } \\
\hline ROA & $1,35 \%$ & $1,55 \%$ & $2,07 \%$ & $1,42 \%$ & $1,38 \%$ & $1,55 \%$ \\
\hline ROE & $26,71 \%$ & $36,94 \%$ & $53,91 \%$ & $37,94 \%$ & $34,14 \%$ & $37,93 \%$ \\
\hline NPF & $2,82 \%$ & $4,75 \%$ & $4,05 \%$ & $3,95 \%$ & $5,72 \%$ & $4,26 \%$ \\
\hline FDR & $97,75 \%$ & $98,90 \%$ & $99,76 \%$ & $103,65 \%$ & $98,11 \%$ & $99,63 \%$ \\
\hline BOPO & $78.91 \%$ & $76.77 \%$ & $76.54 \%$ & $81.75 \%$ & $84.05 \%$ & $79.60 \%$ \\
\hline
\end{tabular}

Sumber: Bank Indonesia (2009), Statistik Perbankan Syariah September 2009 (Jakarta: Direktorat Perbankan Syariah Bank Indonesia), Tabel 35, hal. 35.

Catatan: Data per Desember untuk setiap tahun kecuali data 2009 merupakan data per September.

Secara umum paparan diatas menunjukkan bahwa kontribusi perbankan syariah dalam pembangunan nasional terutama sekali terwujud dalam komitmen membantu masyarakat berkebutuhan modal dengan masyarakat berkelebihan modal. Dengan kata lain, perbankan syariah mampu melaksanakan fungsi intermediasi keuangan yang memadai sekaligus merupakan bagian penting bagi upaya menjaga stabilitas keuangan secara nasional. Namun demikian, sejumlah catatan layak diberikan baik pada pengelola maupun pengambil kebijakan perbankan syariah, terutama terkait peningkatan kontribusi langsung dalam pembiayaan pada sektor-sektor ekonomi yang penting bagi masyarakat. peranan perbankan syariah sudah selayaknya ditingkatkan pada sektor primer yang menjadi tulang punggung ekonomi sekaligus juga dikembangkan pada model akad yang lebih menonjolkan prinsip syariah terutama prinsip bagi hasil. Hal ini penting dilakukan agar tidak muncul kesan bahwa perbankan syariah hanyalah perbankan konvensional dengan wajah yang berlabel syariah semata.

\section{Kesimpulan}

Pembahasan yang dilakukan sebelumnya secara umum menunjukkan bahwa pengembangan perbankan syariah di Indonesia telah didukung oleh pranata hukum yang memadai baik dari aspek legalitas hukum nasional, hukum Islam, maupun dukungan peraturan pendukung operasionalnya. Analisa terhadap data yang digunakan dalam paparan diatas juga menunjukkan bahwa perbankan syariah telah menunjukkan kinerja keuangan yang menggembirakan meskipun perannya masih perlu untuk terus dikembangkan. Perbankan syariah juga telah memberikan kontribusi penting bagi pembangunan nasional dengan melaksanakan fungsi intermediasi keuangan dan menjaga stabilitas keuangan nasional. Peran lain yang kini dituntut dari perbankan syariah adalah partisipasi aktifnya dalam pembiayaan pada sektor primer di Indonesia dan mempraktekkan prinsip syariah terutama prinsip bagi hasil dalam operasionalnya. 


\section{Daftar Pustaka}

Alfitri (2002), "Evaluasi Perkembangan Perbankan Islam di Indonesia", Hermenia, Jurnal Kajian Islam Interdisipliner, Vol. 1, No. 1, Januari-Juni 2002, hal. 1-26.

Andriansyah, Yuli (2006), "Kinerja Keuangan Perbankan Nasional sebelum dan sesudah Fatwa MUI", Laporan Penelitian Mahasiswa dengan Pendanaan Departemen Agama RI, tidak dipublikasikan.

Anshori, Abdul Ghofur (2009), Perbankan Syariah di Indonesia, Yogyakarta: Gadjah Mada University Press.

Bank Indonesia (2002), Cetak Biru Pengembangan Perbankan Syariah Indonesia, Jakarta: Direktorat Perbankan Syariah Bank Indonesia.

(2006), Arsitektur Perbankan Indonesia, dikutip dari http://www. bi.go.id/web/id/Perbankan/Arsitektur+Perbankan+Indonesia/ pada 1 September 2009.

(2006) Statistik Perbankan Indonesia, Vol. 4, No. 7, Juni 2006, Jakarta: Direktorat Perizinan dan Informasi Perbankan Bank Indonesia.

(2009), Statistik Perbankan Indonesia, Vol. 7, No. 10, September 2009, Jakarta: Direktorat Perizinan dan Informasi Perbankan Bank Indonesia.

(2009), Statistik Perbankan Syariah September 2009, Jakarta: Direktorat Perbankan Syariah Bank Indonesia.

Santosa, Perdana Wahyu (2009), "Faktor-faktor yang Mempengaruhi Permintaan Pembiayaan Murabahah Bank Syariah di Indonesia (Periode Januari 2004 - Desember 2008)", Dikta Ekonomi Volume 6 Nomor 2, Agustus 09 / Rajab 1430 H, hal. 101-112.

Zubair, Muhammad Kamal (2008), "Akselerasi Pertumbuhan Bank Syariah di Indonesia" Millah Jurnal Studi Islam, Vol. III, No. 1, Agustus 2008, p. 1-16. 